\title{
Konstitusionalitas Ancaman Pidana Terhadap Kejari (Penetapan Status Barang Sitaan dan Prekursor Narkotika)
}

\author{
Emir Ardiansyah ${ }^{1}$, Ulya Kencana ${ }^{2}$, Romli. SA $^{3}$ \\ ${ }^{1}$ Program Studi Magister Hukum Tata Negara (Siyasah) Fakultas Syariah dan Hukum Universitas Islam Negeri Raden Fatah \\ Palembang, Jl. RW Monginsidi Lr Ramayana No 23a Rt 010 Rw 02 Kalidoni Palembang, \\ ${ }^{2}$ Fakultas Syariah dan Hukum Universitas Islam Negeri Raden Fatah Palembang, \\ Jl. Pembangunan No 5 Rt 002 Rw 009 Siring Agung Ilir Barat 1 Palembang \\ ${ }^{3}$ Fakultas Syariah dan Hukum Universitas Islam Negeri Raden Fatah Palembang, \\ RSS. Kebun Bunga Blok B No.17-18 Rt. 022 Rw 008 Kebun Bunga Sukarame Palembang \\ Correspondence email: emirardiansyahsh@gmail.com); ulyakencana_uin@radenfatah.ac.id); romli_uin@radenfatah.ac.id
}

\begin{abstract}
Abstrak. Kajian tentang konstitusionalitas ancaman pidana terhadap Kejari (Kepala Kejaksaan Negeri) dalam menetapkan status barang sitaan narkotika dan prekursornarkotika, berdasarkan Undang-Undang Republik Indonesia Nomor 35 Tahun 2009 tentang Narkotika sangat perlu dilakukan. Peraturannya bernuansa over criminalization sehingga merugikan hak konstitusional Kejari. Penelitian bertujuan menganalisis peran negara dalam melindungi hak konstitusional Kejari dalam kerangka negara hukum. Ruang lingkup penelitian menjabarkan struktur nilai atau norma dalam peraturan perundang-undangan dan asas yang dianutnya. Asas hukum digunakan dalam menafsirkan Undang-Undang Narkotika dengan mengkaitkannya dalam kerangka negara hukum. Metode penelitian ialah penelitian hukum normatif dengan menggunakan data sekunder. Hasil penelitian mengungkapkan, pengaturan dalam Pasal 141 dan Pasal 91 ayat (1) Undang-Undang Narkotika berpotensi melanggar hak konsitusional Kejari, karena tidak sesuai dengan perlindungan hak konstitusional secara struktur kelembagaan kejaksaan, yang tidak boleh diintervensi dalam penegakan hukum pidana. Disimpulkan, negara berperan besar dalam penyelenggaraan perlindungan hak konstitusional warga negara dan pejabat Kejari. Negara wajib memenuhi, menghormati dan melindungi hak konstitusonal warga negara. Secara kelembagaan, negara bersinergis dengan institusi kejaksaan harus menegaskan wilayah etik dan wilayah administratif secara konkrit dan limitative, sehingga tidak menimbulkan kekaburan norma dan kriminalisasi berlebihan atas perbuatan yang bukan pidana menjadi perbuatan tindak pidana.
\end{abstract}

Kata Kunci: konstitusional, kejaksaan, barang sitaan, narkotika, precursor

\begin{abstract}
Studies on the constitutionality of criminal threats against the Attorney General's Office (Head of the State Prosecutor's Office) in determining the status of confiscated narcotics and narcotic precursors, based on the Law of the Republic of Indonesia Number 35 of 2009 concerning Narcotics, it is very necessary to do so. The regulation has an over-criminalization nuance that is detrimental to the constitutional rights of the Kejari. The research aims to analyze the role of the state in protecting the constitutional rights of the Kejari within the rule of law framework. The scope of the research describes the structure of values or norms in statutory regulations and the principles it adheres to. Legal principles are used in interpreting the Narcotics Law by linking it to the rule of law framework. The research method is normative legal researchusing secondary data. The results of the research revealed that the provisions in Article 141 and Article 91 paragraph (1) of the Narcotics Law have the potential to violate the constitutional rights of the Kejari. because it is not in accordance with the protection of constitutional rights in the institutional structure of the prosecutor's office, which may not be intervened in criminal law enforcement. In conclusion, the state plays a major role in implementing the protection of the constitutional rights of citizens and Kejari officials. The state is obliged to fulfill, respect and protect the constitutional rights of citizens. Institutionally, the state synergizes with the prosecutor's office must affirm the ethical and administrative areas concretely and limitatively, so as not to cause obscurity of norms and excessive criminalization of non-criminal acts to become criminal acts.
\end{abstract}

Keywords: constitutional, prosecutor's office, confiscated goods, narcotics, precursor

\section{PENDAHULUAN}

Indonesia adalah negara hukum, sebagaimana tertera dalam Pasal 1 Ayat (3) Undang-Undang Dasar Republik Indonesia Tahun 1945 (selanjutnya ditulis UUD RI Tahun 1945). Hal ini bermakna, bahwa Indonesia adalah negara hukum yang pelaksanaan ketatanegaraannya dilaksanakan berdasarkan peraturan dan ketentuan yang berlaku. UUD RI Tahun 1945 sebagai konstitusi negara Indonesia merupakan norma sistem politik dan hukum yang dikodifikasikan sebagai dokumen tertulis dimana didalamnya menjabarkan prinsip-prinsip yang menjadi pedoman bagi peraturanperaturan dibawahnya. ${ }^{1}$

Konsep Stahl tentang negara hukum ditandai dengan empat unsur pokok yaitu pengakuan dan perlindungan terhadap hak-hak asasi manusia, negara didasarkan pada teori trias politica, pemerintahan diselenggarakan dengan berdasarkan pada undang- undang, dan terdapat peradilan administrasi negara yang bertugas menangani kasus 
perbuatan melanggar hukum oleh pemerintah (onrechtmatige overheidsdaad). ${ }^{2}$ Sebagai konsekwensi negara hukum, dihadirkan alat-alat kelengkapan negara untuk menyokong ditegakkannya prinsip-prinsip negara hukum, yaitu lembaga penegak hukum. ${ }^{3}$

Kejaksaan sebagai salah satu lembaga penegak hukum dituntut untuk lebih berperan mewujudkan kepastian hukum demi terciptamya ketertiban dan keadilan berdasarkan hukum dengan mengindahkan norma-norma keagamaan, kesopanan, dan kesusilaan, serta wajib menggali nilai-nilai kemanusiaan, hukum, dan keadilan yang hidup dalam masyarakat demi tegaknya supremasi hukum, perlindungan kepentingan umum, penegakan hak asasi manusia, serta pemberantasan kejahatan. ${ }^{4}$

Kemerdekaan dalam melaksanakan kewenangan Kejaksaan dijamin dalam konstitusi. Akan tetapi Kejaksaan memiliki instrumen kontrol untuk mengawasi pelaksanaan tugas dan kewenangannya. Sebagai lembaga negara yang bertugas dibidang penuntutan, yang tertera pada Undang-Undang Nomor 16 Tahun 2014 tentang Kejaksaan Republik Indonesia (selanjutnya disebut Undang-Undang Kejaksaan) telah mengamanatkan Lembaga Majelis Kehormatan Jaksa untuk melakukan pemeriksaan terhadap laporan hasil pemeriksaan Jaksa Agung Muda Pengawasan (JAM WAS), beserta dokumenpendukungnya atau terhadap jaksa yang akan diberhentikan sementara dari jabatannya. ${ }^{5}$

Lembaga Majelis Kehormatan Jaksa (MKJ) mempunyai fungsi kontrol terhadap aparat jaksa yang tidak melaksanakan sumpah atau janjinya sebagai bagian dari aparat negara dan bagian dari penegak hukum. Lembaga ini dapat memberikan rekomendasi sampai dengan yang terberat, yaitu rekomendasi pemecatan terhadap Jaksa yang terbukti melakukan pelanggaran kode etik sebagai formula untuk "mengadili" Jaksa- Jaksa yang melakukan pelanggaran-pelanggaran. ${ }^{6}$

Kejaksaan sebagai bagian dari penegak hukum dalam rangka melaksanakan fungsi penegakan hukum dinilai perlu mengoptimalkan tugas pokok dan fungsi Jaksa dalam menegakkan hukum. Khusus dalam hal penegakan hukum terhadap tindak pidana narkotika. Narkotika merupakan tindak pidana serius. Dalam kenyataannya di masyrakat kejahatan narkotika semakin marak, baik ditinjau dari jumlah pelaku, beragam modus operandi kejahatan, kamuflase bentuk dan jenis kandungan narkotika. Kejahatan narkotika memiliki dimensi kejahatan internasional (International Crime).

Sejak tahun 1971 Perserikatan Bangsa-Bangsa (PBB) dalam Konvensi Pemberantasan Psikotropika (Convention of Psikotropic) di Viena dari tanggal 11 Februari 1971 sampai dengan tanggal 21 Februari 1971 menyoroti permasalahan kejahatan narkotika sebagai kejahatan yang serius (Serious Crime), dan penanganannya juga harus dilakukan serius. Pembahasan dunia internasional berlanjut dari masa ke masa dalam berbagai forum hingga Indonesia meratifikasi Konvensi Perserikatan Bangsa-Bangsa tentang Pemberantasan Peredaran Gelap Narkotika dan Psikotropika Tahun 1988 (United Nation Convention Against Illicit Traffic In Narcotic Drug And Psychotropic Substances, 1988) yang melahirkan Undang-undang Nomor 22 Tahun 1997 tentang Narkotika.

Dalam upaya pemberantasan tindak pidana narkotika, Indonesia melakukan amandemen Undang-Undang Nomor 22 Tahun 1997 tentang Narkotika dengan Undang-Undang Nomor 35 Tahun 2009 tentang Narkotika (selanjutnya disebut Undang-Undang Narkotika). Tujuan perubahan Undang-Undang Narkotika bahwa titik tekannya terdapat dalam penjelasan Undang-Undang Narkotika yang menyebutkan salah satu upaya pemberantasan tindak pidana narkotika, adalah melakukan penguatan lembaga yang sudah ada seperti Badan Narkotika baik di tingkat nasional $(\mathrm{BNN})$ atau ditingkat kabupaten/kota $(\mathrm{BNK}){ }^{7}$

Amandemen Undang-Undang Narkotika pada kenyataannya terdapat sebuah ketentuan yang menyimpang dari maksud dan tujuan perubahan Undang-Undang Narkotika itu sendiri. ${ }^{8}$ Hal ini menyebabkan terciderainya hak konstitusionalitas ancaman pidana terhadap Kejari (selanjutnya ditulis Kepala Kejaksaan Negeri) dalam menetapkan barang sitaan narkotika dan prekursor narkotika. Terdapat ketentuan hukum pada pasal Undang-Undang Narkotika

\footnotetext{
${ }^{2}$ Muhammad Tahir Azhari, Negara Hukum Suatu Studi tentang Prinsip-Prinsipnya dilihat dari Segi Hukum Islam, Implementasinya pada Periode Negara Madinah dan Masa Kini, (Jakarta: Kencana, 2003), hlm. 83-84.

${ }^{3}$ Yang termasuk penegak hukum adalah: 1)Kepolisian; 2)Kejaksaan; 3)Hakim; dan 4)Advokat. Kepolisian, Kejaksaan dan Hakim di peradilan merupakan satuan sistem peradilan pidana terpadu. (Baca Undang-Undang Kepolisian, Undang-Undang Kejaksaan, Undang-Undang Kehakiman, dan Undang- Undang Advokat)

${ }^{4}$ Kesemua prinsip-prinsip kelembagaan kejaksaan diatur dalam kode etik kejaksaan (Baca Peraturan Jaksa Agung Republik Indonesia Nomor 014A/A/JA/11/2012 Tentang Kode Perilaku Jaksa)

${ }^{5}$ Keputusan Jaksa Agung Nomor 017/A/JA/01/2004 tentang Majelis Kehormatan Jaksa.

${ }^{6}$ Selain itu dalam Pasal 38 Undang-undang Kejaksaan telah dibentuk suatu lembaga penunjuang (state auxiliary body) yang bernama Komisi Kejaksaan.Komisi Kejaksaan berfungsi untuk memberikan laporan kinerja Kejaksaan kepada Presiden dan atau Jaksa Agung sebagai bentuk evaluasi namun tidak berarti dapat mengintervensi Jaksa yang menjalankan kewenangannya.

${ }^{7}$ Penjelasan Undang-Undang Nomor 35 Tahun 2009 tentang Narkotika

${ }^{8}$ Konsideran Filosopis, Sosiologis dan Yuridis Undang-Undang 35 Tahun 2009 adalah diperuntukan untuk keselamatan rakyat dan negara dari ancaman kejahatan narkotika, hadirnya Undang-Undang Narkotika diharapkan mampu untuk memberantas kejahatan nerkotika. (Konsideran Undang-Undang 35 Tahun 2009 tentang Narkotika)
} 
yang memuat pemidanaan terhadap Kepala Kejaksaan Negeri atas sebuah tindakan administratif berupa surat penetapan status barang sitaan narkotika dan prekursor narkotika yang dilakukannya tertera pada Pasal 141:

Pasal 91 ayat (1) Undang-Undang Narkotika.

"Kepala Kejaksaan Negeri setempat setelah menerima pemberitahuan tentang penyitaan barang narkotika dan precursor narkotika dari penyidik Kepolisian Negara Republik Indonesia atau penyidik BNN dalam waktu paling lama 7 (tujuh) hari wajib menetapkan status barang sitaan narkotika dan precursor narkotika tersebut untuk kepentingan pembuktian perkara, kepentingan pengembangan ilmu pengetahuan dan teknologi, kepentingan pendidikan dan pelatihan dan/atau dimusnahkan".

Pasal ini mengandung nuansa kriminalisasi berlebihan atau over criminalization. Dimana bila sebuah ketentuan peraturan perundang-undangan menimbulkan kriminalisasi berlebihan dapat mengancam keberlangsungan konsep bahwa negara Indonesia sebagai negara hukum, dikarenakan negara tidak lagi melindungi dan menjamin hak-hak konstitusionalisme. Sebagaimana tertuang dalam UUD RI 1945 yang berdampak pada hilangnya martabat peraturan perundang-undangan dalam negara di mata warga negaranya.

Kepala Kejaksaan Negeri selaku pemangku jabatan struktural di Kejaksaan Negeri, dan mengingat tugasnya menetapkan barang sitaan narkotika dan prekursor narkotika sesuai amanat Undang-Undang Narkotika. Dalam hal ini Kepala Kejaksaan formil administratif di mana pelanggarannya ditindak dengan hukuman administratif yang masuk dalam wilayah kewenangan lembaga etik Kejaksaan bukan dengan pemidanaan. Maka dengan masih berlakunya ketentuan Pasal 141 jo Pasal 91 ayat (1) Undang- Undang Narkotika berpotensi menimbulkan kerugian konstitusional dari pejabat Kepala Kejaksaan Negeri. Kerugian Konstitusional Kepala Kejaksaan Negeri tersebut menjadi ancaman serius bagi terwujudnya hak untuk mendapatkan perlindungan dan jaminan peradilan yang bebas dan mandiri tidak terwujud yang berpotensi melemahkan konsep Indonesia sebagai negara hukum.

Problematika konstitusionalitas Pasal 141 jo Pasal 91 ayat (1) Undang-undang Narkotika yang menimbulkan permasalahan dari aspek hak konstitusional dalam konteks negara hukum. Sehingga perlu kekuasaan pembuat undang-undang dalam menetapkan suatu perbuatan sebagai tindak pidana perlu dikritisi. Mengingat selain ketentuan Pasal 141 jo Pasal 91 ayat (1) Undang-Undang Narkotika sebelumnya telah dikritisi pula mengenai Pasal 99 UndangUndang Sistem Peradilan Pidana Anak, pidana bagi Penuntut Umum yang dengan sengaja tidak melaksanakan kewajibannya dalam Pasal 34 ayat (3). Mahkamah Konstitusi dalam Putusan Nomor 110/PUU-X/2012 menyatakan, bahwa Pasal tersebut inkonsistusional karena menyebabkan kerugian konstitusional bagi pejabat Kejaksaan dalam hal ini Penuntut Umum..$^{9}$ Oleh karenanya tulisan ini memberikan argumentasi terhadap konstitusionalitas ancaman pidana terhadap Kepala Kejaksaan Negeri dalam menetapkan barang sitaan narkotika dan prekursor narkotika menimbulkan kerugian konstitusional pejabat Kepala Kejaksaan Negeri yang berpotensi mengancam konsep Indonesia sebagai negara hukum.

Dari latar belakang tersebut peneliti mengkaji dan menganalisis kedudukan Kepala Kejaksaan Negeri dalam penegakkan hukum pemberantasan peredaran gelap narkotika dalam Undang-Undang Nomor 35 Tahun 2009 tentang Narkotika. Dimana Kepala Kejaksaan Negeri mendapat perlakuan yang tidak adil dengan penegak hukum lainnya dalam undang-undang tersebut. Kepala Kejaksaan Negeri diancam pidana atas suatu perbuatan administrasi, yaitu penetapan barang sitaan narkotika dan precursor narkotika. Sehingga hal ini mengancam hak konstitusional Kepala Kejaksaan Negeri karena tidak sesuai dengan hak asasi manusia sebagaimana diatur dalam pasal 27 UUD 1945, dan adanya kerugian konstitusional Kepala Kejaksaan Negeri terhadap ketentuan Pasal 141 jo Pasal 91 ayat (1) UndangUndang Narkotika.

Oleh karena itu penelitian ini berjudul "Konstitusionalitas Ancaman Pidana Terhadap Kejari (Penetapan Status Barang Sitaan Narkotika dan Prekursor Narkotika)".

\section{Rumusan Masalah}

1. Bagaimana hak konstutional pejabat negara dalam negara hukum ?

2. Bagaimana konstitusionalitas ancaman pidana terhadap Kepala Kejaksaan Negeridalam menetapkan barang sitaan narkotika dan prekursor narkotika?

\section{Tujuan Penelitian}

1. Untuk mengkaji dan menganalisis hak konstutional pejabat negara dalam menetapkan barang sitaan narkotika dan prekursor narkotika

\footnotetext{
${ }^{9}$ Mahkamah Konstiusi, MK: Sanksi Pidana Terhadap Jaksa Inkonstitusional, www.mkri.id, diakses Minggu 4 Oktober 
2. Untuk mengkaji dan menganalisis konstitusionalitas ancaman pidana terhadap Kepala Kejaksaan Negeri dalam menetapkan barang sitaan narkotika dan prekursor narkotika.

\section{Tinjauan Pustaka}

Karya ilmiah yang sejalan dengan tema penelitian sebagai berikut.

Pertama, penelitian Gilang Fajar Shadiq berjudul "Penegakan Hukum Terhadap Pengguna Narkotika Sebagai Pelaku". ${ }^{10}$ Penelitiannya melihat kesenjangan antara teori pengaturan dengan praktik di lapangan terkait penegakan hukum pidana atas pengguna narkotika. Persamaan dengan penelitian sekarang adalah sama-sama melihat penegakan hukum ditataran teori dan praktik berdasarkan ketentuan dalam Undang-Undang Narkotika. Perbedaan dengan penelitian sekarang tentang hak konstitusionalitas ancaman pidana terhadap Kepala Kejaksaan Negeri dalam menetapkan barang sitaan narkotika dan prekursor narkotika.

Kedua,penelitian Amriani berjudul "Kedudukan Kejaksaan dalam Sistem Ketatanegaraan Republik Indonesia (Telaah atas Ketatanegaraan Islam)". ${ }^{11}$ Fokus kajiannya membandingkan pola hak dan kewenangan kejaksaan di Indonesia dengan kejaksaan dalam perspektif hukum Islam. Persamaannya sama membahas mengenai wewenang, tugas, fungsi dan hak-hak kejaksaan yang dilindungi oleh konsitusi. Perbedaannya adalah hak konstitusionalitas ancaman pidana terhadap Kepala Kejaksaan Negeri dalam menetapkan barang sitaan narkotika dan prekursor narkotika.

Ketiga,penelitian Derliana Sari tentang "Optimalisasi Peran Kejaksaan Dalam Pengembalian Kerugian Keuangan Negara Akibat Tindak Pidana Korupsi". ${ }^{12}$ Hasil penelitiannya, bahwa kejaksaan belum dapat mengoptimalkan perannya dalam mengembalikan kerugian keuangan negara. Karena menghadapi beberapa kendala diantaranya kendala dalam peraturan perundang-undangan, sarana dan fasilitas yang terbatas, rendahnya kemauan serta kemampuan para jaksa dalam melacak dan menemukan aset pelaku korupsi. Disarankan agar pemerintah RI segera mengesahkan Undang-Undang Pemberantasan Tindak Pidana Korupsi serta Undang-Undang Pengembalian Aset yang regulasinya diselaraskan dengan UNCAC 2003. Persamaannya persoalan wewenang kejaksaan. Perbedaannya pada hak konstitusionalitas ancaman pidana terhadap Kepala Kejaksaan Negeri dalam menetapkan barang sitaan narkotika dan prekursor narkotika.

Keempat, Penelitian Weliza Ardhiansyah berjudul "Kewenangan Penyadapan SuatuTinjauan Aspek Hak Asasi Manusia di Indonesia (Perlindungan Hak Pribadi Warga Negara dalam Hukum)". ${ }^{13}$ Hasil penelitiannya, bahwa Indonesia sebagai negara hukum Indonesia mengakui hak-hak pribadi warga negaranya sebagai bagian Hak Asasi Manusia, konsep perlindungan hak asassi manusia dalam konteks perlindungan privasi sesorang. Persamaan dengan penelitian sekarang adalah sama-sama mengkaji tentang hak-hak pribadi warga negara Indonesia sebagai bagian HAM. Perbedaannya dengan penulisan jurnal ini adalah HAM terkait dengan tindakan penyadapan. Penelitian sekarang tentang HAM terkait Perlindungan Hak Konstitusional Kepala Kejaksaan Negeri dalam Undang-Undang Narkotika.

\section{Teori Perlindungan Hak Konstitusional}

Perlindungan menurut kamus besar bahasa Indonesia bersal dari kata lindung yang bermakna menempatkan dirinya dibawah (dibalik, dibelakang) sesuatu supaya tidak terlihat atau tidak kena angin, panas, dan sebagainya, sehingga perlindungan bermakna tempat berlindung atau hal (perbuatan dan sebagainya) memperlindungi. ${ }^{14}$

Konstitusional dalam Kamus Besar Bahasa Indonesia diartikan segala ketentuan dan aturan tentang ketatanegaraan (Undang-Undang Dasar dan sebagainya). ${ }^{15}$ Hak konstitusional menurut A. Ahsin Thohari, adalah hakhak warga negara yang diatur dalam konstitusi. ${ }^{16}$

Indonesia sebagai negara hukum dilandasi kepentingan hukum itu sendiri, yaitu mewujudkan keadilan,

${ }^{10}$ Gilang Fajar Shadiq, “Penegakan Hukum Terhadap Pengguna Narkotika Sebagai Pelaku”, Tesis Ilmu Hukum, Program Pascasarjana Magister Ilmu Hukum, (Bandung: Universitas Katolik Payahyangan, 2017). Tidak dipublikasikan.

${ }^{11}$ Amriani, "Kedudukan Kejaksaan dalam Sistem Ketatanegaraan Republik Indonesia (Telaah atas Ketatanegaraan Islam)”, Tesis Ilmu Hukum, Fakultas Hukum dan Syariah, (Makasar: Universitas Alauddin Makassar, 2018). Tidak dipublikasikan.

12 Derliana Sari, “Optimalisasi Peran Kejaksaan Dalam Pengembalian Kerugian Keuangan Negara Akibat Tindak Pidana Korupsi”, Tesis. Ilmu Hukum, Program Studi Magister Fakultas Hukum, (Depok: Universitas Indonesia, 2008), Tidak dipublikasikan.

${ }^{13}$ Weliza Ardhiansyah. "Kewenangan Penyadapan Suatu Tinjauan Aspek Hak Asasi Manusia di Indonesia (Perlindungan Hak Pribadi Warga Negara dalam Hukum)”. Tesis Ilmu Hukum. Tidak dipublikasikan.

${ }^{14}$ Departemen Pendidikan Nasional, Kamus Besar Bahasa Indonesia, (Jakarta: Balai Pustaka, 1986),

${ }^{15}$ Ibid.

${ }^{16}$ A. Ahsin Thohari, Hak Konstitusional dalam Hukum Tata Negara Indonesia, (Jakarta: Erlangga,2016), hlm. 14. 
memberikan kemanfaatan hukum dan kepastian hukum. Dalam konsepsi perlindungan hak konstitusional, maka negara berkewajiban melakukan pemenuhan (to fullpill), penghormatan (to respect) dan perlindungan (to protect) hak hak konsitusional seluruh warga negaranya. Termasuk dalam hal ini pemangku jabatan Kepala Kejaksaan Negeri.

Tugas Kepala Kejaksaan Negeri ialah berfungsi sebagai kepala administratif yang mewakili lembaga Kejaksaan Negeri. Adapun sifat penetapan barang sitaan dan precursor narkotika adalah formil administratif. Hak konstitusional kejari memiliki kewajiban konstitusional yang harus dijalankan, di mana konstitusi UUD NRI 1945 telah mengatur kewajiban negara untuk melindungi hak-hak warga negaranya. Hak konstitusional yang tidak optimal diselenggarakan oleh negara atas perlindunganterhadap Kepala Kejaksaan Negeri dalam hal ini adalah hak atas perlindungan dan perlakuan yang sama dimata hukum. ${ }^{17}$ Termasuk hak Kepala Kejaksaan Negeri atas rasa aman dan perlindungan atas ancaman sebagaimana diatur dalam ketentuan Pasal 28G UUD NRI Tahun 1945 yang berbunyi :

“.. (1) Setiap orang berhak atas perlindungan diri pribadi, keluarga, kehormatan, martabat, dan harta benda yang dibawah kekuasannya, serta berhak atas rasa aman dan perlindungan dari ancaman ketakutan untuk berbuat atau tidak bebruat sesuatu yang merupakan hak asasi.."

Atas dasar hal tersebut, maka perlindungan negara dan pemenuhan negara atas hak-hak konsitusional warga negara dirasa belum optimal diselenggarakan, termasuk dalam hal ini ialah hak warga negara yang merangkap sebagai seorang Kepala Kejaksaan Negeri, karena profesinya sebagai seorang Kejari adalah posisi yang seyogyanya dilindungi dalam rangka optimalitas penyelenggaraan penegakan hukum.

Potensi dapat dipidananya pejabat Kepala Kejaksaan Negeri yang tidak menetapkan objek barang sitaan narkotika, dan sangat besar kemungkinannya apabila tidak ditetapkan lewat pada waktunya. Teori ini dipakai untuk melihat sejauh mana peran negara dalam melakukan pemenuhan perlindungan hak atas rasa aman bagi seluruh warga negaranya termasuk aparat kepala kejaksaan sendiri.

\section{Teori Kriminalisasi Melampaui Batas (Overcriminalization)}

Teori ini dicetuskan oleh Husak. Ia melihat tidak semua hal dapat dijerat pidana, dan pidana hanya digunakan sebagai suatu intrumen terakhir (ultimum remedium). Pemahaman wilayah hukum pidana murni dan wilayah hukum diluar pidana sangat diperlukan dalam proses kriminalisasi. Objek kasus yang dikriminalisasikan tidak selaluberbicara mengenai sanksi pidana.

Konsep kriminalisasi berlebih digunakan Husak untuk menggambarkan fenomena terlalu banyaknya ancaman pidana yang dibuat oleh negara terhadap warganya. ${ }^{18}$ Husak menghasilkan teori kriminalisasi, yaitu"... normative framework to distinguishthose criminal laws that are justified fromthose that are not. Pendapat Husakpada hakikatnya merupakan tanggapan atas fenomena di Amerika Serikat yang menurutnya "we overpunish andovercriminalize."

\section{METODE}

Jenis penelitian ialah penelitian hukum normatif. Jhony Ibrahim menyatakan, penelitian hukum normatif merupakan suatu prosedur penelitian ilmiah dalam rangka menemukan suatu kebenaran berdasarkan logika keilmuan dari perspektif normatifnya. ${ }^{19}$ Peter Mahmud Marzuki menambahkan, penelitian hukum merupakan suatu proses untuk menemukan aturan hukum, doktrin-doktrin hukum dalam rangka menjawab suatu isu hukum. ${ }^{20}$ Penelitian normatif dimaksudkan sebagai prosedur penelitian ilmiah untuk menemukan kebenaran berdasarkan logika keilmuan dari sisi normatifnya.

Penelitian ini secara normatif menelaah Konstitusional Kepala Kejaksaan Negeri Dari Ancaman Pidana Dalam Menetapkan Status Barang Sitaan Narkotika dan Precursor Narkotika pada Undang-Undang Republik Indonesia Nomor 35 Tahun 2009 Tentang Narkotika.

Sumber bahan hukum yang digunakan yaitu:

a. Bahan Hukum Primer, ialah bahan hukum yang bersifat autoratif artinya memiliki otoritas dan mengikat. ${ }^{21}$ Bahan hukum primer dalam penelitian adalah Undang-Undang Nomor 35 Tahun 2009 tentang Narkotika.

b. Bahan Hukum Sekunder

Bahan hukum sekunder adalah semua publikasi tentang hukum yang bukan merupakan dokumen-dokumen resmi sebagai bahan hukum yang memberikan penjelasan mengenai bahan hukum primer, yaitu hasil-hasil penelitian dan

${ }^{17}$ Pasal 28 ayat (1) UUD NRI Tahun 1945 : Setiap orang berhak atas pengakuan, jaminan, perlindungan, dan kepastian hukum yang adil serta perlakuan yang sama dihadapan hukum.

${ }^{18}$ Douglas Husak, Overcriminalization: The Limits of the Criminal Law. (Oxford University Press:2008), hlm. 3.

${ }^{19}$ Jhonny Ibrahim, Teori dan Metode Penelitian Hukum Normatif, (Malang: Byumedia, 2006), hlm. 47.

${ }^{20}$ Peter Mahmud Marzuki, Penelitian Hukum, (Jakarta: Kencana, 2007), hlm. 35.

${ }^{21}$ Peter Mahmud Marzuki, Penelitian Hukum, Cet. 14, (Jakarta: Prenadamedia, 2019), hlm. 181. 
hasil karya dari kalangan hukum yang ada relevansinya dengan persoalan hukum yang dikaji.

c. Bahan Hukum Tersier, ialah bahan yang memberikan petunjuk maupun penjelasan terhadap bahan hukum primer dan tersier, seperti kamus, ensiklopedia, indeks kumulatif, dan sebagainya. ${ }^{22}$

Teknik pengumpulan bahan hukum melakukan penelaahan bahan hukum yang diperoleh dari literatur kepustakaan seperti Peraturan perundang-undangan tentang Narkotika, Buku-buku teks, Jurnal Ilmiah, Hasil penelitian yang relevan dengan tema penelitian.

Teknik analisis bahan hukum yaitu :

a. Teknik analisis deskriptif, yaitu dengan cara menjabarkan struktur nilai atau norma dalam peraturan perundangundangan beserta asas-asas yang dianut dalam hierarki tata urutan perundang-undangan. Setelah itu penulis menjabarkan ratio decidendi dari asas-asas hukum dari peraturan tersebut. Hal ini yang dinamakan ilmu hukum sebagai ilmu yang preskriptif. Penulis menggunakan peraturan perundang-undangan yang berkenaan dengan isu hukum yang dibahas dan menganalisisnya melalui konsep ilmu hukum yang relevan. Selanjutnya, dilakukan upaya penemuan hukum (rechtsvinding) dan pembentukan hukum (rechtsvorming) yang bersifat praktisfungsional dengan cara penguraian yang teleologis-konstruktif.

b. Tataran teknis, yaitu menghimpun, menata, dan memaparkan aturan hukum pada Undang-Undang Dasar Tahun 1945, Undang-Undang Nomor 16 Tahun 2004 tentang Kejaksaan, dan Undang-Undang Nomor 35 Tahun 2009 tentang Narkotika berdasarkan hierarki sumber hukum untuk membangun landasan legitimasi dalam menafsirkan aturan hukum positif dengan menerapkan metode logika sehingga tertata dalam suatu sistem yang koheren.

c. Tataran teleologis, yaitu mensistematisasi peraturan hukum berdasarkan substansi hukum, dengan cara menata ulang dan menafsirkan meterial yuridis dalam perspektif teleologis, sehingga sistemnya menjadi lebih jelas dan berkembang dengan menerapkan metode teleologis sebagai patokan sistematisasi internalnya.

Pendekatan yang digunakan dalam penelitian, yaitu :

a. Pendekatan Filosofis (Philosopycal Approach). Digunakan untuk menganalisis persoalan hukum secara menyeluruh, spekulatif tetapi mendasar.

b. Pendekatan Peraturan Perundang-undangan(Statute Approach). Digunakan untuk mengkaji berbagai aturan hukum positif yang merupakan fokus sekaligus tema sentral suatu penelitian hukum normatif dengan memahami norma hukum positif dariperaturan perundangan-undangan terkait yaitu:

1) Undang-Undang Dasar Tahun 1945.

2) Undang-undang Nomor 16 Tahun 2014 tentangKejaksaan Republik Indonesia.

3) Undang-Undang Nomor 35 Tahun 2009 tentang Narkotika.

Teknik penarikan kesimpulan menggunakan logika berfikir deduktif, yaitu penalaran (hukum) yang berlaku umum pada kasus individual dan konkrit (persoalan hukum faktual yang konkrit). Proses yang terjadi dalam deduksi adalah konkritisasi (hukum), karena temuan-temuan hukum berupa nilai-nilai, asas-asas, konsep-konsep, dan normanorma hukum yang dirumuskan secara umum dalam aturan-aturan hukum positif, kemudian dikonkritisasi (dijabarkan) dan diterapkan guna penyelesaian persoalan hukum konkrit yang dihadapi, sehingga diperoleh kesimpulan sebagai jawaban atas permasalahan hukum yang diajukan sebelumnya.

Asumsi kesimpulan penelitian ini adalah pengaturan dalam Pasal 141 dan Pasal Pasal 91 ayat (1) UndangUndang Narkotika adalah berpotensi melanggar hak konsitusional kepala kejaksaan negeri yang secara konseptualitas. Perbuatan penetapan barang sitaan yang tidak ditetapkan dalam jangka waktu 7 (tujuh) hari, adalah perbuatanpidana dan diancam dengan pidana penjara. Hal ini tidak sesuai dan tidak proporsional dengan perlindungan hak konstitusional Kepala Kejaksaan secara struktur kelembagaan kejaksaan tidak boleh diintervensi dalam penegakkan hukum pidana, maupun tidak proporsional secara fungsional yang melekat pada subjek hukum pemangku jabatan kepala kejaksaan dalam fungsinya sebagai Kepala Kejaksaan dan Kepala Administrasi Pelayanan Lembaga Jaksa ditingkat Kejaksaan Negeri. Menurut peneliti ini adalahwilayah administrasi dan wilayah etik yang penyelesaiannnya bukan melalui tindak pidana melainkan melalui peradilan etik kejaksaan.

\section{HASIL DAN PEMBAHASAN}

\section{Peran Negara Dalam Melindungi Hak Konstitusional}

Negara adalah sebuah organisasi politik karena merupakan tata aturan yang berisi aturan-aturan penggunaan paksaan dan negara memonopoli penggunaan paksaan tersebut. ${ }^{23}$ Selain itu negara terdiri atas suatu masyarakat yang terorganisasi secara politik dan merupakan komunitas yang dibentuk berdasarkan tata aturan yang bersifat memaksa

\footnotetext{
${ }^{22}$ Ibid.

${ }^{23}$ Jimly Ashiddiqie, dan M. Ali Safaat, Teori Hans Kelsen tentang Hukum, (Jakarta: KonstitusiPress, 2007).
} 
yang dinamakan hukum. Dalam konteks ini negara dipandang sebagai institusi yang legalistik dan normatif, sehingga model negara yang demikian menempatkan negara sebagai lembaga state centris, di mana segala hal yang tersedia dalam negara merupakan kebijakan yang didasarkan pada pertimbangan pejabat publik atau administrasi negara.

Konsep negara demikian banyak dikritik karena kekhawatiran adanya menipulatif pemaksaan negara terhadap warganya. Hal ini wajar terjadi karena ada aktor-aktor di luar organisasi politik sebuah negara mempunyai andil dalam menentukan arah dan tujuan negara dalam mewujudkan keadilan bagi seluruh warga negaranya. Keadilan merupakan hak asasi pengakuan dan perlindungan Hak Asasi Manusia (selanjutnya ditulis HAM) dalam konstitusi sebuah negara.

Hubungan yang terbangun antara konstitusi dan HAM dengan berbagai macam dinamikanya memunculkan konsep yang disebut dengan konsep hak konstitusional(constitutional rights). Sehingga secara sederhana konsep hak konstitusional dikatakan sebagai hak hukum warga negara atau kemungkinan warga negara lain yang berada dalam yuridiksi, yang hak hukum itu mendapat perlindungan dalam konstitusi dari sebuah negara yang berdaulat.

Konsep hak konstitusional di Indonesia dapat dikatakan sebagai hak yang diberikandan diatur dalam UUD RI 1945. Pengertian ini juga yang dianut dalam Pasal 51 ayat (1) Undang-Undang Nomor 24 tahun 2003 tentang Mahkamah Konstitusi yang menyatakan, bahwa "Yang dimaksud dengan hak konstitusional adalah hak-hak yang diatur dalam Undang-undang Dasar Negara Republik Indonesia Tahun 1945". ${ }^{24}$ Sehingga hak konstitusional dalam negara Indonesia dipahami sebagai hak yang dijamin perlindungannya oleh UUD RI Tahun 1945 yang pada akhirnya dari hak konstitusional tersebut melahirkan Hak Legal (legal Rights) warga negara Indonesia yang jaminan perlindungan lahir dari peraturan perundang-undangan dibawah UUD RI 1945 (subordinate legislation).

UUD RI 1945 merupakan konstitusi negara Indonesia didalamnya terkandung prinsip pengakuan dan perlindungan hak-hak konstitusional oleh negara. Prinsip ini mengandung adanya jaminan ditegakkannya HAM, adanya pembagian kekuasaan dalam negara, penyelenggaraan yang didasarkan pada undang-undang, dan penyelenggaraannya berdasarkan Undang-Undang Republik Indonesia Nomor 24 Tahun 2003 tentang Mahkamah Konstitusi,Lembar Negara Nomor 98 Tahun 2003, Tambahan Lembar Negara Nomor 4316. Hal ini menegaskan hak konstitusional merupakan identitas dari konsep negara hukum yang mengandung sejumlah nilai diantaranya, yaitu nilai kebebasan artinya kemampuan untuk memilih model dan bentuk kehidupan, memperbaiki sasaran jangka panjang dan efektif untuk mengarahkan kehidupan seseorang sesuai cita-cita negara.

Dengan konsep negara hukum diharapkan terwujudnya masyarakat yang adil yang mencakup aspek demokrasi, dan pemenuhan hak-hak dasar rakyat yang dijamin pengakuan dan perlindungannya dalam undang-undang dasar dan turunannya. Hukum merupakan rule of the game yang akan mencegah atau menghalangi penguasa dan warganya bertindak sewenang-wenang, sehingga hukum diartikan suatu piranti yang memberikan perlindungan atas ketentraman umum dan keadilan rangka mewujudkan kesejahteraan masyarakat. Sehingga supremasi hukum dalam sebuah negara hukum adalah landasan dalam penyelenggaraan negara termasuk melindungi hak warga negaranya yang dilaksanakan tidak saja sebatas hukum dibuat, namun bagaimana hukum dapat terlaksana dengan baik sebagaimana mana fungsi hukum itu sendiri.

Perlindungan konstitusional berdasarkan perumusan prinsip-prinsip negara hukum menurut F.J. Stahl ditinjau ulang dalam International Commision of Jurist pada konferensi yang diselenggarakan di Bangkok tahun 1965 sebagai berikut:

a. Perlindungan konstitusional, artinya selain menjamin hak-hak individu konstitusi harus pula menentukan prosedur untuk memperoleh perlindungan atas hak-hak yang dijamin.

b. Badan Kehakiman yang bebas dan tidak memihak.

c. Pemilihan Umum yang bebas.

d. Kebebasan menyatakan pendapat.

e. Kebebasan berserikat/berorganisasi dan beroposisi.

f. Pendidikan Kewarganegaraan.

Terkait dengan perlindungan HAM, maka Jimly Ashiddiqie memformulasikan 12 prinsip pokok yang harus dimiliki dari sebuah negara hukum baik yang bersifat the rule of law maupun yang bersifat rechtstaat dalam arti sebenarnya yaitu supremasi hukum (supremacy of law), persamaan didalam hukum (equality befor the law), asas legalitas (due process of law), pembatasan kekuasaan, organ eksekutif yang merdeka, peradilan bebas yang tidak memihak, Peradilan Tata Usaha Negara, Peradilan Tata Negara (constitutional court), perlindungan hak asasi manusia, demokratis, berfungsi mewujudkan tujuan negara, dan transparasi dan kontrol sosial.

Dalam rangka penegakan hukum, jaminan dan perlindungan HAM diwujudkan dengan tujuan untuk memberikan kepastian hukum bagi seluruh warga negara Indonesia. Sehingga badan-badan peradilan yang melaksanakan penegakkan hukum diberikan hak dan kewajiban untuk merwujudkan kemanfaatan hukum bagi masyarakat sehingga setiap hasil penegakkan hukum memberikan mashlahat bagi kehidupan berbangsa dan bernegara.

${ }^{24}$ Dahlan Thaib, dkk, Teori Hukum dan Konstitusi. (Jakarta: PT. Rajagrafindo Persada, 2015), Cet.ke-12, hal. 73. 
Oleh karena itu lembaga peradilan dalam melaksanakan tugas dan fungsinya mutlak dilakukan secara merdeka dan tidak memihak.

Kewajiban negara atas warga negara yang merangkap sebagai seorang KepalaKejaksaan Negeri, selain dilihat dari aspek definisi warga negara di dalam kewarganegaraan, di sisi lain dapat dilihat dan sangat relevan dikaji dengan teori strukturisasi Anthony Giddens, ${ }^{25}$ menjelaskan seorang Pemangku Jabatan (prive) dan jabatannya adalah dua dikotomi yang tidak bisa dipisahkan. Sehingga diantara kedua hal tersebut akan saling mempengaruhi. Artinya seorang warga negara yang juga sebagai seorang Kepala Kejaksaan tetap dianggap sebagai seorang warga negara Indonesia, sehingga hak dan kewajibannya sebagai warga negara Indonesia kecuali yang dibatasi oleh peraturan perundang-undangan tetap melekat baginya.

Dalam perspektif hukum tata negara positif, jabatan merupakan pribadi (person). Hukum tata negara tidak lain dari keseluruhan kaidah-kaidah khusus yang berlaku terhadap sikap tindak atau perilaku pemangku jabatan tertentu. ${ }^{26}$ Oleh karena jabatan tidak bisa bertindak sendiri, maka jabatan bertindak dengan perantaraan wakilnya yakni manusia sebagai pemangku jabatannya. Terkait perwakilannya muncul apabila terjadi ketidakselarasan antara kebutuhan untuk bertindak dan kemampuan untuk bertindak, baik sebagai subjek kewajiban maupun sebagai subjek hak. Jabatanjabatan tanpa pejabat akan senantiasa bersifat abstrak, dan oleh karenanya membutuhkan kehadiran pejabat untuk mengkonkritkan jabatan-jabatan tersebut.

Mengikuti konstruksi berpikir seperti ini maka dapat dilihat tanpa hadirnya individu pejabat tidak akan terlaksana fungsi dan peranan Kejaksaan khususnya sebagai seorang Kepala Kejaksaan. Negara memiliki kewajiban dan keharusan untuk melindungi hak- hak Kepala Kejaksaan Negeri termasuk hak-haknya sebagai individu warga negara, yaitu hak atas perlindungan dan perlakuan yang sama dimata hukum.

Perlidungan hak konstitusional Kepala Kejaksaan Negeri tersebut menjadi problematika dan dinilai tidak linear dengan kehendak konstitusi dengan hadirnya pengaturan terkait ancamana pidana bagi Kepala Kejaksaan Negeri yang tidak menetapkan status barang sitaan selama 7 (tujuh) hari. Ancaman tersebut tidak hanya dilihat dalam kacamata perlindungan hukum negara atas Kepala Kejaksaan semata, tetapi juga bagaimana peran dan perlindungan negara terhadap warga negaranya yang berprofesi sebagai seorang Kepala Kejaksaan Negeri.

Hak konstitusional yang tidak optimal diselenggarakan oleh negara atas perlindungan terhadap Kepala Kejaksaan Negeri, dalam hal ini adalah hak atas perlindungan dan perlakuan yang sama dimata hukum. ${ }^{27}$ Berdasarkan Pasal 28 ayat (1) UUD RI Tahun 1945, bahwa

\section{"Setiap orang berhak atas pengakuan, jaminan, perlindungan, dan kepastian hukum yang adil serta perlakuan} yang sama dihadapan hukum".

Termasuk pula hak Kepala Kejaksaan Negeri atas rasa aman dan perlindungan atas ancaman sebagaimana diatur dalam ketentuan Pasal 28G UUD RI Tahun 1945 yang berbunyi :

"Setiap orang berhak atas perlindungan diri pribadi, keluarga, kehormatan, martabat, dan harta benda yang dibawah kekuasannya, serta berhak atas rasa aman dan perlindungan dari ancaman ketakutan untuk berbuat atau tidak berbuat sesuatu yang merupakan hak asasi”.

Disimpulkan negara dalam kaitannya dengan Kepala Kejaksaan dengan atau tanpa warga negaranya berprofesi sebagai Kepala Kejaksaan atau bukan, maka negara tetap dituntut berperan secara aktif untuk melindungi dan memenuhi serta menyelenggarakan hak-hak konsitusional warganegaranya.

Kepentingan penyelenggaraan perlindungan hak konsitusinonal warga negara semakin krusial apabila warga negaranya merangkap sebagai pejabat publik, sebagai Kepala Kejaksaan Negeri. Hal ini terkait erat dengan kemerdekaan Kepala Kejaksaan Negeri yang juga sebagai Jaksa. Kemerdekaan dalam melaksanakan kewenangan Kejaksaan dijamin dalam konstitusi. Namun bukan artinya Kejaksaan tidak memiliki instrumen kontrol untuk mengawasi pelaksanaan tugas dan kewenangan Kejaksaan. Sebagai lembaga negara yang bertugas dibidang penuntutan, Undang-Undang Nomor 16 Tahun 2014 tentang Kejaksaan Republik Indonesia (selanjutnya disebut Undang- Undang Kejaksaan) telah mengamanatkan Lembaga Majelis Kehormatan Jaksa (selanjutnya ditulis MKJ) untuk melakukan pemeriksaan terhadap laporan hasil pemeriksaan Jaksa Agung Muda Pengawasan (JAM WAS) beserta dokumen pendukungnya atau terhadap Jaksa yang akan diberhentikan sementara dari jabatannya. ${ }^{28}$

${ }^{25}$ Abdul Firman Ashaf, "Pola Relasi Media, Negara dan Masyarakat: Teori Strukturisasi Anthony Giddens sebagai alternatif”, Jurnal Sosiohumaniora, Vol. 8, No.2, (Juli 2006), 205-218. Jurusan Ilmu Komunikasi FISIP, Universitas Lampung: 7.

${ }^{26}$ Ibid.

${ }^{27}$ Keputusan Jaksa Agung Nomor 017/A/JA/01/2004 tentang Majelis Kehormatan Jaksa.

${ }^{28}$ Selain itu dalam pasal 38 Undang-undang Kejaksaan telah dibentuk suatu lembaga penunjuang (state auxiliary body) 
MKJ mempunyai fungsi kontrol terhadap aparat Jaksa yang tidak melaksanakan sumpah atau janjinya sebagai bagian dari aparat negara dan bagian dari penegak hukum. Lembaga ini dapat memberikan rekomendasi sampai dengan yang terberat yaitu rekomendasi pemecatan terhadap Jaksa yang terbukti melakukan pelanggaran kode etik sebagai formula untuk "mengadili" Jaksa-Jaksa yang melakukan pelanggaran- pelanggaran. ${ }^{29}$ Adanya MKJ disisi lain untuk menjaga etika dan moralitas profesi Jaksa.

Etika secara umum digunakan dalam prinsip-prinsip sesuatu profesi. Prinsip-prinsip orang perorangan atau individu untuk menjalankan suatu profesi hukum tertuju pada suatu moralitas. Jaksa sebagai profesi hukum harus dilaksanakan secara profesional. Seorang profesional hukum memiliki dua peranan yang terkait satu sama lain, yaitu sebagai pengemban etika profesi hukum dan moralitas hukum. Hubungan antara etika dan profesi hukum menurut Lubis, ${ }^{30}$ bahwa etika profesi adalah sikap hidup, yang mana berupa kesediaan untuk memberikan pelayanan profesional di bidang hukum terhadap masyarakat dengan melibatkan secara penuh keahliannya sebagai pelayanan dalam melaksanakan tugas sebagai kewajibannya. Sehingga dalam melaksanakan profesi terdapat kaidah-kaidah pokok yang disebut etika profesi. ${ }^{31}$

Perlindungan dan pemenuhan akan HAM merupakan unsur pokok untuk sebuah dinegara diidentifikasikan sebagai suatu negara hukum. UUD RI Tahun 1945 sebagai konstitusi negara Indonesia merupakan norma sistem politik dan hukum yang dikodifikasikan sebagai dokumen tertulis di mana didalamnya menjabarkan prinsip- prinsip yang menjadi pedoman bagi peraturan-peraturan dibawahnya. ${ }^{32}$

Prinsip-prinsip keadilan dalam pengakuan hak konstitusional juga dicontohkan olehRasulullah Sallallhu'Alaihi Wasallam. Zainal Abidin Ahmad menyebut prinsip-prinsip Madinah dengan piagam (charter), ${ }^{33}$ karena isinya mengakui hak-hak warga sehingga dapat dijadikan sebagai hak konstitusional seperti hak kebebasan beragama dan berkeyakinan, kebebasan berpendapat dan kehendak umum warga Madinah supaya terwujud keadilan dalam kehidupan masyarakat Madinah.

Rasulullah sebagai kepala negara dan pemerintah pada waktu itu senantiasa menjalankan prinsip syura atau musyawarah dimana Rasulullah menghargai pendapat sahabat dan dalam pengambilan suatu keputusan. Selain itu dalam pemerintahan pada masa Nabi Muhammad Sallallhu'Alaihi Wasallam pengakuan terhadap hak-hak warga negara ditegakkan dengan prinsip keadilan yang nyata dengan dicetuskan konstitusi Madinah (Madinah Chapter). Konstitusi Madinah merupakan konstitusi pertama di muka bumi benar-benar menerapkan pengakuan, jaminan, dan perlindungan HAM. Dalam Konstitusi Madinah tidak saja jaminan perlindungan HAM oleh negara kepada kaum muslimin, namun juga kepada kaum kafir. Kondisi masyarakat Madinah pada saat itu merupakan masyarakat heterogen yang terdiri dari dua suku besar yang selalu berkonflik yaitu suku Aus dan suku Khazraj, masing-masing suku bersekutu dengan Yahudi yakni bani Qhuraizhah dan bani Nadhir.

Dengan dicetuskannya konstitusi Madinah oleh Rasulullah kedua suku tersebut hidup damai berdampingan bahkan Konstitusi Madinah dapat menyatukan penduduk Madinah baik pendatang dengan penduduk asli Madinah, serta dapat mempersaudarakan kaum Muhajirin dan kaum Anshar. Keberhasilan Rasulullah Sallallhu'Alaihi Wasallam dalam mempersatukan penduduk Madinah dengan menerapkan Konstitusi Madinah. Hal itu tidak lepas dari ajaran Rasulullah Sallallhu'Alaihi Wasallam memperkenalkan konsep bernegara, yakni memberikan perlindungan dengan wawasan kerukunan dan perdamaian, sehingga menciptakan suatu tatanan masyarakat yang toleran, akomodatif dan menghargai perbedaan pandangan sesama penduduk Madinah termasuk pandangan dalam beragama satu sama lain.

Persamaan kedudukan antar warga Madinah sebagaimana disepakati dalam Konstitusi Madinah nampak didalam kehidupan beragama, perlindungan dan kesetaraandalam hukum disebutkan:

a. Siapapun yang berbuat zhalim dan jahat baik dari kalangan muslim maupun yahudi tidak boleh dilindungi oleh siapapun bahkan harus ditentang bersama-sama.

b. Dilarang melakukan main hakim sendiri,dan bersekongkol dengan lawan.

c. Selama tidak melakukan pelanggaran kaum Yahudi, dan sekutunya berhak mendapat perlindungan, pertolongan dan jaminan negara.

d. Baik kaum muslimin maupun Yahudi diberikan kebebasan melaksanakan untuk menjalankan tuntunan agamanya masing-masing.

yang bernama Komisi Kejaksaan. Komisi Kejaksaan berfungsi untuk memberikan laporan kinerja Kejaksaan kepada Presiden dan atau Jaksa Agung sebagai bentuk evaluasi namun tidak berarti dapat mengintervensi Jaksa yang menjalankan kewenangannya.

${ }^{29}$ Suhrawadi K. Lubis, Etika Profesi Hukum, (Jakarta: Sinar Grafika, 1994), hlm. 6

${ }^{30}$ Ibid. 6.

${ }^{31}$ Dahlan Thaib, 1999. Op.Cit. 11.

${ }^{32}$ Ahmad Sukardja, Piagam Madinah dan Undang-Undang Dasar 1945, (Jakarta: UI Press, 1995),hlm. 2.

${ }^{33}$ Oxford Dictionary. Op.Cit. 
Dalam perspektif Islam, Kejaksaan merupakan wujud penyelesaian permasalahan dan representasi penegakan hukum yang menyangkut dan menyelesaikan persoalan kehidupan bermasyarakat, sehingga sepatutnya pengakuan hak konstitusional juga berlaku sama rata terhadap Jaksa dan Pejabat di Kejaksaan tersebut agar dapat melaksanakan tugas dan fungsinya secara merdeka guna menegakkan supremasi hukum.

\section{Konstitusionalitas Ancaman Pidana Terhadap Kepala Kejaksaan Negeri Dalam Menetapkan Barang Sitaan Narkotika Dan Prekursor Narkotika}

Makna konstitusionalitas dalam bahasa Inggris adalah constitutionality yaitu kenyataan yang sesuai dengan konstitusi. ${ }^{34}$ Refli Harun mengartikan konstitusionalitas adalah konsisten dengan konstitusi; disahkan oleh konstitusi; selaras dengan hukum dasar negara berlaku yaitu konstitusi. Konstitusi dalam negara memiliki kedudukan sebagai legitimasi hak-hak warga negara yang pengakuan dan penjaminan hak itu bertujuan sebagai penjaga ketertiban dan pelindung dari kesewenang-wenangan penguasa/negara. Konstitusi memberikan peran negara untuk mengatur hak-hak warga negara tersebut dengan memperhatikan batas-batas hak warga negara yang diakui dalam konstitusi negara. Konstitusi memiliki tiga muatan pokok yaitu penjaminan HAM, ketatanegaraan tersusun secara mendasar, dan pembagian serta pemisahan kekuasaan. ${ }^{35}$ Prinsip-prinsip tersebut dalam ketatanegaraan modern dikenal sebagai konsep negara hukum.

Berdasarkan konstitusi diketahui Undang-Undang Dasar sebuah negara akan diketahui negara itu, baik bentuk kedaulatannya maupun sistem pemerintahannya. Seperti halnya Indonesia sebagai negara berbentuk Republik, Indonesia sebagai negara hukum pelaksanaan ketatanegaraannya dilaksanakan berdasarkan peraturan dan ketentuan yang berlaku.

Dalam perspektif filosofis pembentukan Undang-Undang Nomor 35 Tahun 2009 tentang Narkotika, semangat pembentukan dari Undang-Undang Narkotika semata-mata ditujukan untuk lebih mengefektifkan pemberantasan narkotika secara paripurna dalam rangka melindungi kepentingan bangsa. Hal ini dikarenakan Undang-Undang Nomor 22 Tahun 1997 sudah tidak sesuai dengan perkembangan situasi dan kondisi yang berkembang untuk menanggulangi dan memberantas tindak pidana peredaran gelap narkotika.

Ketentuan Pasal 141 Undang-Undang Narkotika bermuatan pemidanaan atas perbuatan dalam tataran administratif formal penanganan perkara narkotika, yaitu perbuatan tidak menetapkan barang bukti narkotika atau prekursor narkotika dalam kurun waktu 7 (tujuh) hari. Menurut black's laws dictionary, bahwa hukum administrasi adalah cabang hukum yang diciptakan badan-badan administrasi untuk melaksanakan kekuasaan dan tugasnya dalam bentuk peraturan, regulasi, perintah, dan keputusan.

Definisi tersebut mengandung arti penetapan benda sitaan narkotika dan prekursor narkotika masuk dalam bentuk keputusan badan administrasi, yaitu Kepala Kejaksaan Negeri karena secara undang-undang Kepala Kejaksaan Negeri diberi tugas untuk menetapkan barang sitaan narkotika dan prekursor narkotika. Maka penetapan barang sitaan tersebut merupakan perbuatan administrasi. Perbuatan administrasi menurut

Muchsan, ${ }^{36}$ ialah perbuatan untuk merealisasikan apa yang diatur dalam peraturan perundang-undangan. ${ }^{37}$

Berdasarkan Undang-Undang Administrasi Pemerintahan, tindakan administrasi adalah tindakan pejabat pemerintahan atau penyelenggara negara lainnya untuk melakukan dan/atau tidak melakukan perbuatan konkret dalam rangka penyelenggaraan pemerintahan. Problemnya adalah adanya tindakan administratif yang dijatuhkan sanksi pidana atau yang dikenal dengan administrative penal law. Menyikapi hal ini bila dirujuk pada teori Hans Kelsen yang menyatakan peraturan perundang-undangan yang memiliki dimensi tertentu atau khusus tidak dapat dicampuradukkan antara satu dengan lainnya. Hal ini sesuai dengan asa hukum lex spesialis systemic derograd lex generaly artinya perbuatan administratif tidak dapat disamakan dengan perbuatan pidana.

Seorang pejabat penyelenggara negara yang melaksanakan tugasnya sesuai undang-undang atau mengeluarkan kebijakan tidak dapat dipertanggungjawabkan pidananya manakala didalam pengeluaran tersebut tidak terjadi penyalahgunaan wewenang oleh pejabat tersebut seperti mengambil keuntungan bagi diri sendiri atau orang lain, sehingga menimbulkan kerugian negara atau hak orang lain dilanggar secara melawan hukum. Hal ini menjadi penting agar tidak terjadi tumpang tindih pengaturan dan penghukuman. Penyelesaian dari suatu kesalahan tindakan administratif diselesaikan dalam prosedur administratif, seperti melalui sanksi administratif atau pemberian sanksi melalui komisi etika pofesi atau dengan tetapi menjatuhkan pemidanaan dengan revisi peraturan yang lebih ketat seperti adanya penyalahgunaan wewenang dari pejabat tersebut.

Masuknya perbuatan administrasi yang diberi penghukuman dengan pidana dalam Pasal 141 Undang-Undang

${ }^{34}$ Oxford Dictionary. Op.Cit.

${ }^{35}$ Sri Soemantri, M, Prosedur dan Sistem Konstitusi, (Bandung: Alumni, 1979), hlm. 136.

${ }^{36}$ Muchsan, Peradilan Administrasi Negara. (Yogyakarta: Liberty, 1981).

${ }^{37}$ Dinoroy Marganda Aritonang, Aspek Hukum Penyelenggaraan Administrasi Publik di Indonesia, (Bandung: PT. Refika Aditama, 2019), hlm. 154. 
Narkotika tidak seharusnya terjadi, karena penghukuman yang tidak setimpal dengan perbuatannya. Hal ini dikategorikan sebagai kriminalisasi berlebihan (over criminalization). Ashworth berpendapat dalam memandang kriminalisasi berlebihan atau melampaui batas, menurutnya kriminalisasi dikaitkan dengan keberlakuan bidang-bidang hukum lainnya sebagai instrumen bagi negara dalam melakukan pengaturan, maka kriminalisasi suatu tindakan adalah ultimum remedium. ${ }^{38}$

Disamping berlandaskan kepada asas legalitas, kebijakan kriminalisasi juga harus berdasarkan kepada asas subsidiaritas, artinya hukum pidana harus ditempatkan sebagai ultimum remedium (senjata pamungkas) dalam penanggulangan kejahatan yang menggunakan instrumen penal, bukan sebagai primum remedium (senjata utama) untuk mengatasi masalah kriminalitas. Penerapan asas subsidiaritas dalam kebijakan kriminalisasi dan dekriminalisasi mengharuskan adanya penyelidikan tentang efektivitas penggunaan hukum pidana dalam penanggulangan kejahatan atau perbuatan-perbuatan yang merugikan masyarakat. Penggunaan asas subsidiaritas dalam praktek perundangundangan ternyata tidak berjalan seperti diharapkan.

Hukum pidana tidak merupakan ultimum remedium melainkan sebagai primium remedium. Penentuan pidana telah menimbulkan beban terlalu berat dan sangat berlebihan terhadap para justitiable dan lembaga-lembaga hukum pidana. ${ }^{39}$ Kenyataan yang terjadi dalam praktek perundang-undangan adala $\mathrm{h}$ adanya keyakinan kuat dikalangan pembentuk undang-undang, bahwa penetapan suatu perbuatan sebagai perbuatan terlarang yang disertai dengan ancaman pidana berat mempunyai pengaruh otomatis terhadap perilaku anggota masyarakat.

Latar belakang semakin perlunya menggunakan asas subsidiaritas dalam penentuan perbuatan terlarang didorong oleh dua faktor:

1) Pertama, penggunaan asas subsidiaritas akan mendorong lahirnya hukum pidanayang adil.

2) Kedua, praktek perundang-undangan menimbulkan dampak negatif terhadap sistem hukum pidana akibat adanya overcriminalization dan overpenalisation sehingga hukum pidana menjadi kehilangan pengaruhnya dalam masyarakat. Di samping itu, over kriminalisasi dan over penalisasi semakin memperberat beban kerja aparatur hukum dalam proses peradilan pidana. Akibat selanjutnya, hukum pidana tidak dapat berfungsi dengan baik dan karenanya pula kehilangan wibawa. ${ }^{40}$

Asas lain yan berkedudukan penting dalam proses kriminalisasi, yaitu asas persamaan/kesamaan. Kesamaan adalah kesederhanaan dan kejelasan. Kesederhanaan serta kejelasan itu menimbulkan ketertiban. Menurut Servan dan Letrossne asas kesamaan bukan pernyataan dari aspirasi tentang hukum pidana yang lebih adil. Asas kesamaan lebih merupakan suatu keinginan diadakannya sistem hukum pidana yang lebih jelas dan sederhana. ${ }^{41}$ Lacretelle berpendapat bahwa asas kesamaan tidak hanya suatu dorongan bagi hukum pidana yang bersifat adil, tetapi juga untuk hukuman pidanayang tepat. ${ }^{42}$

Over criminalization memiliki beberapa parameter bagi suatu peraturan yang bermuatan over criminalization, yaitu hukuman yang tidak proporsional, penegakkan hukum atas pelanggaran-pelanggaran kecil, dan mengandung pemahaman kesalahan yang sangat luas. Douglas Husak menjelaskan bahwa terdapat dua alasan over criminalization tidak dikehendaki yang pertama adalah over criminalization menyebabkan banyaknya penghukuman pidana yang tidak layak dan tidak dibenarkan, kedua over criminalization mengancam konsep negara hukum. ${ }^{43}$

Pendapat Husak beralasan karena dalam sebuah negara yang berdasarkan hukum dan demokrasi seperti Indonesia, kekuasaan untuk melegalisasi kriminalisasi dalam peraturan perundang-undangan ada pada negara, yaitu pemerintah dan legislator. Menurut Bassiouni, keputusan untuk melakukan kriminalisasi dan dekriminalisasi harus didasarkan pada faktor-faktor kebijakan tertentu yang mempertimbangkan bermacam- macam faktor termasuk :

a) Keseimbangan sarana yang digunakan dalam hubungannya dengan hasil-hasilyang ingin dicapai.

b) Analisis biaya terhadap hasil-hasil yang diperoleh dalam hubungannya dengantujuan-tujuan yang ingin dicari.

c) Penilaian atau penaksiran tujuan-tujuan yang dicari itu dalam kaitannya dengan prioritas-prioritas lainnya dalam pengalokasian sumber-sumber tenaga manusia.

d) Pengaruh sosial kriminalisasi dan dekriminalisasi yang berkenaan dengan atau dipandang dari pengaruh-

${ }^{38}$ Marthen H Toelle. Kriminalisasi Berlebih dari Kriminalisasi Korupsi, Jurnal Refleksi Hukum, Vol.9, No. 2: 120.

39 Antonie A.G. Peter, Asas Hukum Pidana Dalam Perspektif, (Jakarta: Aksara Baru, 1981), hlm. 58.

40 Roeslan Saleh, Kebijakan Kriminalisasi Dan Dekriminalisasi: Apa Yang Dibicarakan Sosiologi Hukum Dalam Pembaruan Hukum Pidana Indonesia, (Yogyakarta: Fakultas Hukum UII, 1993). hlm. 48.

${ }^{41}$ Ibid.

42 Ibid. hlm. 36-37

43 Douglas Husak, Overcriminalization dalam Dennis Patterson (ed), A Companion to Philosophy of Law and Legal Theory, (Blackwell Publishing Co.: 2010). hlm. 62. Sebagaimana dikutip dalam Moeljatno, Asas-asas Hukum Pidana, (Bandung: Rineka Cipta, 1993). 
pengaruhnya yang sekunder. ${ }^{44}$

Hans Kelsen dalam karyanya "The Pure Theory of Law" menyatakan , bahwa "negara suatu ketertiban dari norma-norma hukum yang mengikat yang menjadikan negara adalah identik dengan hukum, kemudian setiap organ negara identik dengan organ hukum yang mengindikasikan suatu negara merupakan personifikasi dari hukum. Ia mengakui teori hukum murninya adalah suatu teori monistis yang justru mengeliminasi dari adanya dualisme antara keadilan dan hukum, negara dan hukum, dan hukum subjektif dan objektif". 45

Sebagai asas dan prinsip konsep, negara hukum memiliki dasar yang kuat untuk melegitimasi supremasi hukum, maka dari itu dalam negara hukum pembuat undang- undang berperan besar dalam menentukan kriminalisasi suatu perbuatan yang mana hal ini membuka peluang terjadinya kesewenang-wenangan pembuat undang-undang dalam menentukan kriminalisasi suatu perbuatan dalam peraturan perundang-undangan.

Dengan demikian kriminalisasi berlebih mencerminkan adanya kesewenangan- wenangan pembuat undangundang. Maka untuk mencegah hal ini dalam sebuah negara hukum perlu adanya pembatasan agar tidak terjadi kesewenang-wenangan dan merugikan hak konstitusional warga negara. Pasal 141 Undang-Undang Narkotika dimana dalam ketentuan tersebut memuat hukuman yang tidak proporsional, penghukuman pidana terhadap pelanggaran administratif, dan memperluas penjatuhan sanksi pidana selain perbuatan pidana peredaran gelap narkotika yang tidak sesuai dengan maksud Undang-Undang Narkotika, merupakan bentuk ketentuan yang melanggar hak konstitusional Kepala Kejaksaan Negeri karena bertentangan dengan hakkonstitusional sebagaimana diatur dalam UUD 1945 dalam pasal $28 \mathrm{D}$ ayat (1) yang berbunyi :

"setiap orang berhak mendapatkan pengakuan, perlindungan, dan kepastian hukum yang adil serta perlakuan yang sama dihadapan hukum" dan pasal 28 G yang berbunyi "Setiap orang berhak atas perlindungan diri pribadi, keluarga, kehormatan, martabat, dan harta benda yang dibawah kekuasannya, serta berhak atas rasa aman dan perlindungan dari ancaman ketakutan untuk berbuat atau tidakberbuat sesuatu yang merupakan hak asasi”.

Secara teoretis hak untuk tidak dikriminalisasi secara tidak adil dan tidak beralasan mengandung konteks pembatasan terhadap kekuasaan negara untuk melakukan kriminalisasi, dengan pengertian supaya kriminalisasinya legitimate maka kriminalisasi tersebut harus adil dan berdasar. Perlunya akal budi untuk menghasilkan pemahaman inter-subjektif guna menjelaskan sifat tercela atau jahatnya perbuatan (the wrongness of action) sebagai justifikasi bagi kriminalisasi yang dilakukan.

Kriminalisasi berlebih dari Pasal 141 jo Pasal 91 ayat (1) Undang-undang Narkotika menyebabkan Kepala Kejaksaan Negeri mengalami kerugian hak konstitusional. Sehingga ketentuan Pasal 141 Undang-undang Narkotika menjadi inkonstitusional atau bertentangan dengan konstitusi UUD RI 1945. Oleh sebab itu, idealnya untuk menyikapi kelalaian dalam melaksanakan fungsi administratif adalah melalui upaya hukum administratif atau dapat menggunakan instrumen penyelesaian dalam menyikapi situasi aparat kejaksaan baik secara struktural maupun fungsional yang tidak melaksanakan kode etik dan kewajiban administratif, yaitu melalui Lembaga Majelis Kehormatan Jaksa.

Bila terjadi pelanggaran profesionalisme Jaksa dapat ditindak melalui mekanisme yang berlaku di Komisi Kejaksaan. Selain itu guna meluruskan kembali norma dalam Pasal 141 Undang-Undang Narkotika dapat dilakukan Judicial Review oleh Kepala Kejaksaan Negeri ke Mahkamah Konstitusi dengan memohon untuk Mahkamah konstitusi sebagi negative legislator untuk menyatakan Pasal 141 Undang-Undang Narkotika tersebut inkonstitusional. Sebagaimana sebelumnya dilakukan oleh Ikatan Hakim Indonesia dan Persatuan Jaksa Indonesia yang melakukan jucicial review terhadap Pasal 99 Undang-Undang Nomor 11 tahun 2012 tentang Sistem Peradilan Pidana Anak, pidana bagi Jaksa Penuntut Umum yang dengan sengaja tidak melaksanakan kewajibannya dalam Pasal 34 ayat (3). Sebagai contoh dalam putusan Mahkamah Konstitusi dalam Putusan Nomor 110/PUU-X/2012 yang mengabulkan permohonan Persatuan Jaksa Indonesia untuk menyatakan Pasal 99 Undang-Undang Sistem Peradilan Pidana Anak inkonstitusional.

Putusan a quo diatas merupakan sebuah potret bahwa pengaturan tindak pidana administrasi yang terdapat dalam undang-undang dikoreksi oleh Mahkamah Konstitusi. Dalam putusan a quo dapat dicermati pula, bahwa ketentuan pidana menjadi primum remidium, prinsip-prinsip hukum pidana semisal asas legalitas terlanggar, serta tidak terakomodasinya prinsip keadilan. Selain itu, ketiadaan ukuran dan parameter kapan suatu materi muatan pasal/ayat atau bagian dari suatu undang-undang perlu memuat ketentuan pidana atau tidak. ${ }^{46}$ Dengan demikian,

\footnotetext{
${ }^{44}$ Barda Nawawi Arief, Bunga Rampai Kebijakan Hukum Pidana, (Bandung: Citra Aditya Bhakti, 1996).

45 Wahyudin Husein, Hukum Politik dan Kepentingan, (Yogyakarta: LaksBang. 2008). hlm. 28.

${ }^{46}$ Titis Anindyajati, et. al, "Konstitusionalitas Norma Sanksi Pidana sebagai Ultimum Remediumdalam Pembentukan
} 
penetapan suatu perbuatan merupakan tindak pidana administrasi merupakan agenda politik kriminal yang penting dan terbuka guna pembentukan undang-undang di masa yang akan datang

Dengan masih berlakunya Pasal 141 Undang-Undang Narkotika menyebabkan hak konstitusional Kepala Kejaksaan Negeri dirugikan sehingga berdampak pada penurunanharkat martabat Kepala Kejaksaan Negeri yang akan berdampak pada independensi Jaksa dalam melaksanakan tugas sebagaimana dimaksud dalam Undang-Undang Kejaksaan Republik Indonesia.

\section{SIMPULAN}

Berdasarkan hasil penelitian disimpulkan :

1. Hak konstutional pejabat negara dalam negara hukum, bahwa Negara berperan dalam melindungi hak konstitusional dalam kerangka negara hukum. Negara berperan besar dalam penyelenggaraan perlindungan hak konstitusional warga negara secara umum, termasuk pejabat Kepala Kejaksaan Negeri. Negara mengeembankan kewajiban memenuhi (to fullpill), menghormati (to respect) dan melindungi (to protect) hak konstitusonal warga negaranya. Hak atas perlindungan dan perlakuan yang sama dimata hukum, hak atas rasa aman dan perlindungan dari ancaman sebagai amanah dari konstitusi Undang-Undang Dasar Negara Republik Indonesa Tahun 1945. Negara perlu untuk menegaskan peran dan kewajibannya tersebut ke dalam norma peraturan perundang- undangan secara konsisten. Diperlukan penguatan norma dan proporsional sanksi ditataran legislasi peraturan perundangundangan yang mengatur sanksi atas tidak terselenggaranya aktifitas administratif pejabat Kejaksaan Negeri.

2. Konstitusionalitas ancaman pidana terhadap Kepala Kejaksaan Negeri dalam menetapkan barang sitaan narkotika dan prekursor narkotika, bahwa ketentuan Pasal 91 ayat (1) jo. Pasal 141 Undang-Undang Nomor 35 Tahun 2009 tentang Narkotika dinilai inkosntitusional. Mengingat sanksi pidana atas tindakan adminitratif dinilai tidak proporsional, dan hal tersebut dinilai tidak adil dan tidak sesuai dengan nafas pembentukan Undang-Undang Nomor 35 Tahun 2009 tentang Narkotika. Selain itu, penyelesaian atas kelalaian pejabat Kepala Kejaksaan atas tidak ditetapkannya barang sitaan pada waktunya, adalah masuk dalam wilayah etik dan administrtaif, sehingga metode penyelesaiannya adalah masuk wilayah Majelis Kehormatan Jaksa (MKJ). Secara kelembagaan, negara bersinergis dengan institusi kejaksaan harus menegaskan wilayah etik dan wilayah administratif secara konkrit dan limitative, sehingga tidak menimbulkan kekaburan norma dan kriminalisasi berlebihan atas perbuatan yang bukan pidana menjadi perbuatan tindak pidana. Masyakarat dan pemerintah perlu bersinergis dalam menciptakan tata kelola etika dan administrasi Kejaksaan yang optimal dalam mendukung upaya penyelenggaraan penegakan hukum.

\section{Saran}

Dalam rangka perwujudan penegakan hukum yang berkeadilan disarankan :

1. Pasal 141 Undang-undang Narkotika perlu direvisi. Adapaun revisi ini dapat ditempuh di badan legislatif. Bentuk revisi Pasal 141 Undang-Undang Narkotika dapat ditempuh dalam dua model yaitu :

a. Mencabut ketentuan pidana Pasal 141 Undang-Undang Narkotika baik pidana badan maupun pidana denda;

b. Merevisi ketentuan Pasal 141 Undang-Undang Narkotika dengan membuat kriteria tambahan agar perbuatan administratif menetapkan barang sitaan narkotika dan prekursor narkotika dapat dijatuhi pidana. Kriteria tambahan tersebut adalah adanya kriteria perbuatan melawan hukum Kepala Kejaksaan Negeri tidak menetapkan barang sitaan narkotika dan prekursor narkotika secara melawan hukum dalam arti pidana seperti penyalahgunaan wewenang untuk mengambil keuntungan pribadi atau orang lain.

2. Langkah yang paling tepat terhadap keberlakuan Pasal 141 Undang-Undang Narkotika adalah dengan mengajukan judicial review oleh para Kepala Kejaksaan Negeri ke Mahkamah Konstitusi memohon agar Pasal 141 dinyatakan inkonstitusional karena bertentangan dengan Pasal 28 D dan Pasal 28 G UUD RI 1945.

\section{DAFTAR PUSTAKA \\ Buku}

Arief, Barda Nawawi, Bunga Rampai Kebijakan Hukum Pidana, (Bandung: Citra Aditya Bhakti, 1996).

Aritonang, Dinoroy Marganda, Aspek Hukum Penyelenggaraan Administrasi Publik di Indonesia,(Bandung: PT. Refika Aditama, 2019).

Ashiddiqie, Jimly, dan M. Ali Safaat, Teori Hans Kelsen tentang Hukum, (Jakarta: Konstitusi Press, 2007).

Azhari, Muhammad Tahir, Negara Hukum Suatu Studi tentang Prinsip-Prinsipnya dilihat dari Segi Hukum Islam, Implementasinya pada Periode Negara Madinah dan Masa Kini, (Jakarta: Kencana, 2003).

Husein, Wahyudin, Hukum Politik dan Kepentingan, (Yogyakarta: LaksBang, 2008).

Husak, Douglas, Overcriminalization: The Limits of the Criminal Law. Oxford 
Emir Ardiansyah et al., Konstitusionalitas Ancaman Pidana Terhadap Kejari (Penetapan Status Barang Sitaan dan Prekursor Narkotika)

University Press, (2008).

Ibrahim, Jhonny, Teori dan Metode Penelitian Hukum Normatif, (Malang: Byumedia,2006).

Lubis, Suhrawadi K, Etika Profesi Hukum, (Jakarta: Sinar Grafika, 1994).

Marzuki, Peter Mahmud, Penelitian Hukum, Cet. 14, (Jakarta: Prenadamedia, 2019).

------, Penelitian Hukum, (Jakarta: Kencana, 2007).

Moeljatno, Asas-asas Hukum Pidana, (Bandung: Rineka Cipta, 1993). Muchsan, Peradilan Administrasi Negara, (Yogyakarta: Liberty, 1981).

Saleh, Roeslan, Kebijakan Kriminalisasi dan Dekriminalisasi: Apa Yang Dibicarakan Sosiologi Hukum Dalam Pembaruan Hukum Pidana Indonesia, (Yogyakarta: Fakultas Hukum UII, 1993).

Soemantri, Sri, Prosedur dan Sistem Konstitusi, (Bandung: Alumni, 1979).

Sukardja, Ahmad, Piagam Madinah dan Undang-Undang Dasar 1945, (Jakarta: UI-Press, 1995).

Thaib, Dahlan, Teori Hukum dan Konstitusi, (Jakarta: Raja Grafindo Persada, 1999).

-----. dkk. Teori Hukum dan Konstitusi, Cet.ke-12, (Jakarta. PT. Rajagrafindo Persada,2015).

Peter, Antonie A.G, Asas Hukum Pidana Dalam Perspektif, (Jakarta: Aksara Baru,1981).

Patterson, Dennis (ed). A Companion to Philosophy of Law and Legal Theory.

Blackwell Publishing Co.

Peter, Antonie A.G., Asas Hukum Pidana Dalam Perspektif, (Jakarta: Aksara Baru,1981).

\section{Jurnal}

Abdul Firman Ashaf, "Pola Relasi Media, Negara dan Masyarakat: Teori Strukturisasi Anthony Giddens sebagai alternatif", Jurnal Sosiohumaniora, Vol. 8, No.2, (Juli 2006). 205-218. Jurusan Ilmu Komunikasi FISIP, Universitas Lampung.

Marthen H Toelle, "Kriminalisasi Berlebih dari Kriminalisasi Korupsi”, Jurnal Refleksi Hukum, Vol.9, No. 2.

Titis Anindyajati, et. al, "Konstitusionalitas Norma Sanksi Pidana sebagai Ultimum Remedium dalam Pembentukan Perundang-undangan", Jurnal Konstitusi, Vol.12, No.4,Desember (2015).

Tesis

Gilang Fajar Shadiq, "Penegakan Hukum Terhadap Pengguna Narkotika Sebagai Pelaku”, Tesis Ilmu Hukum, Program Pascasarjana Magister Ilmu Hukum, (Bandung: Universitas Katolik Payahyangan, 2017), Tidak dipublikasikan.

Amriani, "Kedudukan Kejaksaan dalam Sistem Ketatanegaraan Republik Indonesia (Telaah atas Ketatanegaraan Islam)", Tesis Ilmu Hukum, Fakultas Hukum dan Syariah, (Makasar: Universitas Alauddin Makassar, 2018), Tidak dipublikasikan.

Derliana Sari, "Optimalisasi Peran Kejaksaan Dalam Pengembalian Kerugian Keuangan Negara Akibat Tindak Pidana Korupsi", Tesis. Ilmu Hukum, Program Studi Magister Fakultas Hukum, (Depok: Universitas Indonesia, 2008), Tidak dipublikasikan.

Weliza Ardhiansyah. "Kewenangan Penyadapan Suatu Tinjauan Aspek Hak Asasi Manusia di Indonesia (Perlindungan Hak Pribadi Warga Negara dalam Hukum)”, Tesis Ilmu Hukum.

\section{Kamus}

Departemen Pendidikan Nasional, Kamus Besar Bahasa Indonesia, (Jakarta: BalaiPustaka, 1986).

\section{Internet}

Mahkamah Konstiusi, MK: Sanksi Pidana Terhadap Jaksa Inkonstitusional,www.mkri.id, diakses pada Minggu 4 Oktober 2020.

\section{Peraturan}

Undang-Undang Republik Indonesia Tahun 1945

Undang-Undang Republik Indonesia 35 Tahun 2009 tentang Narkotika.

Undang-Undang Republik Indonesia Nomor 24 Tahun 2003 tentang MahkamahKonstitusi.

Penjelasan Undang-Undang Nomor 35 Tahun 2009 tentang Narkotika.

Peraturan Jaksa Agung Republik Indonesia Nomor 014A/A/JA/11/2012 tentang KodePerilaku Jaksa.

Keputusan Jaksa Agung Nomor 017/A/JA/01/2004 tentang Majelis Kehormatan Jaksa. Lembar Negara Nomor 98 Tahun 2003 tentang Mahkamah Konstitusi.

Tambahan Lembar Negara Nomor 4316 tentang Mahkamah Konstitusi. 